\title{
基于关注心理契约维护问题探讨高校青年教师职业倦急的解决 方案
}

\author{
党亚男 韦旭豪 \\ 东莞职业技术学院 \\ DOI:10.12238/mef.v3i8.2773
}

\begin{abstract}
[摘 要] “心理契约” 是美国著名管理心理学家施恩教授提出的名词。他认为, 心理契约是 “员工将 有所奉献与组织欲望有所获取之间，以及组织将针对员工期望收获而有所提供的一种配合”。通俗易懂 的说, 即组织能否有效满足员工的心理期待。它虽然不是一种正式的契约，但它却同样是影响员工行 为的重要因素，与正式契约相比有着不可替代的作用。
\end{abstract}

[关键词] 心理契约; 职业倦急; 高校

中图分类号: G41 文献标识码: A

\section{Discussing the Solutions to the Job Burnout of Young Teachers in Colleges and Universities Based on the Maintenance of Psychological Contract \\ Ya'nan Dang, Xuhao Wei \\ Dongguan Polytechnic}

\begin{abstract}
[Abstract] "Psychological contract" is a term put forward by the famous American management psychologist Professor Schein. He believes that the psychological contract is "a kind of cooperation between the employee's contribution and the organization's desire to obtain, and the organization's cooperation in response to the employee's expectation and gain." In plain language, it is whether the organization can effectively meet the psychological expectations of employees. Although it is not a formal contract, it is also an important factor affecting employee behavior, and has an irreplaceable role compared with a formal contract.
\end{abstract}

[Key words] psychological contract; job burnout; colleges and universities

高校教师作为职业倦急的高发人 群，并未说明职业倦怠是从事教师职业 的必然结果, 职业倦急的形成其实是与 个体对工作的感知密切相关的; 而心理 契约可以从员工与组织互动的角度了解 员工在组织中的心理需要及心理需要的 实现度，这对于预防、缓解、甚至消除 高校教师的职业倦急感有着重要的作 用。就目前来说, 我国高校教师群体对 于高校组织的心理契约一般有: 个人提 升、充足薪酬、工作保障、职业发展性、 工作内容及时间。当高校教师的以上需 求未能够很好的实现时, 高校教师与学 校之间的平衡受到破坏, 就会出现 “心 理契约违背”。教师职业相比一般的职业 在工作时需要投入更多的情感资源, 与
之对应, 教师也更希望自身的心理期望 能够得到满足; 而当教师的心理期望长 期不能很好的满足, 出现 “心理契约违 背” 时, 教师会不自觉的减少自身情绪 资源在工作中的投入, 而他们自身的情 绪资源也在枯竭, 职业倦急自然被诱发。 心理契约论不仅能够解释高校教师的职 业倦怠感的成因, 也能够基于此提出行 之有效的解决方法。

造成高校教师产生职业倦急感的原 因有多方面的, 如: 教师职业工作内容 较为固定, 单一性强, 长时间重复相同 的工作内容容易引起教师的职业倦怠 感; 教师职业具有光环效应, 光环效应 会让从事教师职业的人群承受更多的压 力并且会禁锢教师的个性, 引起教师工
作角色与生活角色混乱, 这是光环效应 引发教师职业倦急; 个人对工作的预期 与现实工作情况之间的差距会让高校教 师形成心理落差, 从而引起职业倦急; 高校教师的教师专业发展意识不够强 烈, 即没有明确的职业生涯规划, 教师 对自我能力认识不足且能力提升较慢, 工作中会出现 “力不从心” 的情况等等。 虽然原因不同，但归根结底都是通过影 响高校教师的心理状态使其产生职业倦 急感。心理契约理论探讨的是个人如何 与组织进行互动, 且影响组织的能力。 如果个体在工作中能感觉到因为自己的 付出从而使工作对象得到充分的改善, 则其心理契约的成就感与满意度将会提 高, 进而激发其对职业的认同与热情; 
反之，若未能达到预期标准时，就会降 低个体对于工作的积极性, 并从而产生 职业倦怠感。心理契约理论的核心是员 工满意度, 员工满意度的高低取决于员 工的心理期望能否被很好的满足。从高 校教师个人角度出发去看待心理契约理 论, 心理契约理论的核心内容直接影响 了高校教师对于职业工作的态度与行 为; 因此我们根据心理契约理论, 通过 调整高校教师的心理预期, 增加其对于 职业工作的热情、提高高校教师对于职 业的满意度与认同度的方式，来达到预 防、缓解、消除高校教师职业倦急感的 目的。

\section{1 高校教师授课内容多样性、}

\section{授课时间阶段性}

教师职业工作内容固定, 单一性强, 长时间重复相同的工作内容容易引起教 师的职业倦急感。我们可以适当的增加 高校教师的授课内容，或允许高校教师 在不偏离课程基础的前提下自行拓展; 且授课方式可以灵活多变, 不仅是课堂 教学; 高校还可以对教师的教学工作做 出适当调整, 如负责教导专业理论的教 师可以在教导理论课两年后去担任实习 课程的任课老师。高校教师职业倦怠感 的出现也有一个阶段性, 其出现也是需 要经历一个过程。高校教师工作内容丰 富，工作岗位灵活，可以规避高校教师 出现职业倦怠感的时间节点, 从而达到 缓解、消除高校教师职业倦怠感的目的。

\section{2 对教师开展心理指导课、减} 压课

教师职业具有光环效应，光环效应 会让从事教师职业的人群承受更多的压 力并且会禁锢教师的个性, 引起教师工 作角色与生活角色混乱。高校教师因为 教师职业自带的光环效应而面临心理压 力过大、无法正确区分工作角色与生活 角色的问题。通过对教师开展心理指导 课、减压课, 去帮助高校教师正确看待 自身职业、合理转变自身角色，从而使 从事教师职业的人群更好的适应教师这 一职业。

3 多种方法降低或满足心理预期 个人对工作的预期与现实工作情况
之间的差距会让高校教师形成心理落 差，从而引起职业倦急。高校教师对自 身职业预期不全面的原因在于没有充分 认识该职业。可通过对从事教师的人群 进行岗前培训, 增加他们对于高校教师 职业的认识, 从而降低他们的心理预期; 学校可丰富奖惩机制, 让高校教师看到 关于未来发展的更多可能性去明确他们 的工作目的性、增加他们的工作积极性, 从而获得职业认同感，满足预期。

\section{4 开展职业生涯规划指导课程}

教师缺乏明确的生涯规划, 自身职 业素养提高缓慢, 无法很好处理工作中 的问题, 这会打击教师的工作信心, 使 教师产生挫败感, 这也是诱发教师形成 职业倦怠感的原因。可以定期为教师开 展职业生涯规划指导课程, 去帮助教师 主动为自身职业发展未来做出规划; 这 有利于教师确立个人发展目标, 弥补自 身不足, 发展自身优势从而实现目标。 最重要的是为教师提供一个自我评估的 重要机会。教师可以根据规划的进展情 况评价他当前取得的成果, 这可以激励 教师努力工作，充分发挥其潜能。

\section{5 扩大教师交际圈}

配偶问题得不到解决也是高校教师 产生职业倦急感的原因之一。通过开展 各种形式的联谊活动来扩大高校教师的 交际圈。如各高校教师工会之间的联谊、 社区讲座、还有晚会等。此类活动可以 有效扩大高校教师的交际圈, 增加其与 适婚异性的接触, 为高校教师解决配偶 问题带来的压力提供途径; 还可以加深 教师对于学校的认同感与归属感。

\section{6 保障教师进行兴趣爱好活动}

\section{的时间}

高校教师的兴趣爱好得不到充分的 发挥与培养, 不利于高校教师的压力释 放、不利于高校教师的心理健康。学校 留给高校教师一定的进行兴趣爱好的时 间可以帮助高校教师缓解工作压力, 有 利于教师的身心健康发展; 而有组织的 进行集体兴趣爱好活动还可以加强教师 之间的沟通, 增进教师与教师之间的友 谊。并且促进了教师的多样化发展。

\section{7 结束语}

尽管心理契约只是一种无形的契 约, 但它确实存在, 而且它是影响教师 对待职业工作态度与行为的一个重要因 素。心理契约不仅包括着教师期望在学 校组织中获得的回报: 自我提升、实现 等, 还包括着学校组织对于员工的一种 期望, 如希望教师对学校工作尽职尽责、 乐于奉献等。如果教师的心理期望能够 得到满足, 他们则往往会体验到满足感, 这会让他们热情积极地去完成职业工 作; 而与此同时学校也能够获得更好的 绩效, 这可以形成一种良性循环, 既大 大减少了高校教师职业倦急的形成, 又 促进了高校学术治学的氛围。

\section{基金项目:}

2019年东莞职业技术学院质量工程 项目 “基于心理学视角探讨高校青年教 师的职业倦急与心理契约维护问题” (编 号JGZD201854)。

\section{[参考文献]}

[1]袁博.高校青年教师相对剥夺感 及其成因研究 [D].重庆工商大学,2018.

[2]王琛.高职院校青年教师职业倦 急管理问题及对策研究 [D]. 西北大 学,2018.

[3]刘舒文.高校青年教师职业倦急 现象对策探析 [J]. 科学大众(科学教 育),2018(02):167.

[4]刘舒文.高校青年教师职业倦急 现象的现状与思考 [J].太原城市职业技 术学院学报,2017(11):73-74.

[5]郭杰.高校青年教师职业倦急的 现状、影响因素及对策研究---以中国 石油大学 (华东) 为例 [J]. 山东工会论 坛,2017,23(05):30-34.

[6]王万民,侣黎明.高校实施青年教 师EAP的调查与建议---以曲阜师范大学 为例[J]. 山东工会论坛,2017,23(2):45-47.

[7]王鹏程,董君成。高校青年教师职 业倦急感及其影响因素研究---基于对 塔里木大学2 40 名青年教师的调查问卷 [J].人力资源管理,2016(08):211-212.

\section{作者简介:}

党亚男（1984-- ), 女，汉族，辽 宁彰武人, 助理研究员, 本科, 研究方 向: 心理学。 